\title{
The Antibiotics Group Aminoglycosides and Macrolides on Beef in Bali
}

\author{
Siswanto $^{1}$, I Nyoman Sulabda ${ }^{1}$ \\ ${ }^{1}$ Laboratory of Physiology, Faculty of Veterinary Medicine \\ Udayana University, Denpasar, Bali \\ *Corresponding Author: siswanto@unud.ac.id
}

\begin{abstract}
Animal products may contain certain ingredients that are not good for human health, such as antibiotic residues. The aim of this research is to know the residue of aminoglycoside and macrolide group antibiotics in Bali beef marketed in Bali-Indonesia. The study used 60 samples of meat from merchant in five different markets: Negara, Tabanan, Denpasar, Singaraja, and Klungkung, where each market was taken 12 samples. Screening tests used to determine antibiotic residues in meat. The results showed only 4 positives from 60 samples containing antibiotics, aminoglycoside 2 sempels $(3.33 \%)$ and marcrolide 1 sempel $(1.67 \%)$.
\end{abstract}

\section{Keywords: residues, aminoglycoside, marcrolide, beef, screening tests.}

\section{INTRODUCTION}

Antibiotics are used in the animal husbandry and veterinary to control and or eradicate diseases caused by bacteria [1], [2], [3], [6], [9]. Often the meat on the market contains antibiotic residues, and if consumed by the humans will a bad effect on health. If a continuous occurrence will bacterial immunity to consumers [7], [11].

Antibiotics are substances that can kill or inhibit bacterial growth, there are various types or classes of antibiotics, including: penicillin, polypeptides and cephalosporins, for example ampicillin, penicillin $G$ works through inhibitors of bacterial cell wall synthesis. The quinolone group, for example rifampicin, actinomycin D, nalidixic acid works through transcription and replication inhibitors. macrolides, aminoglycosides, eg gentamicin, chloramphenicol, kanamycin, streptomycin, tetracycline, oxytetracycline, erythromycin, and azithromycin work through protein synthesis inhibitors. The ionomycin group, valinomycin works through inhibitors of cell membrane function. Sulfa or sulfonamides, for example oligomycin, tunicamycin. Antimetabolites, such as azaserine $[4,5,8,14]$
Masrianto reported the absence of antibiotic residues in beef in West Java, but the results of monitoring in Sulawesi were aminoglycoside residues in beef $0.6 \%$ and tilosine $2.7 \%$ [7]. From time to time antibiotic residues in meat products are always found on the market. Therefore, observe meats marketed to monitoring antibiotic residues. The purpose of this observation is to find out antibiotic residues on beef marketed in Bali. The benefit is information to the government and the consumer, so that humans will be more careful in consuming beef. The results of the study can also be used as routine monitoring of the presence or absence of antibiotics in products of animal.

As many as 3 of 24 positive beef samples were found for macrolide antibiotic residues [17]. Shareef et al (2009) found that the highest concentration of antibiotic residues found in meat was tetracycline $(8 \%)$ followed by ampicillin (4\%), streptomycin (2\%) and aminoglycoside $(1 \%)$ compared to other antibiotics such as sulfonamides, neomycin and gentamicin. A total of 28 antibiotics were analyzed using a LCMS/MS screening method and sulfonamides, fluoroquinolones, and 
tilmicosin were detected in some of the samples [19]. From the study are concluded that the occurrence of antibiotic remnants in poultry meat [12]. From 75 samples from the first abattoir two positive samples were found, while in the second there were no positive samples from breast muscles. The great number of samples with antimicrobial residues was found in kidneys and livers of the chicken [10].

From the description above it was concluded that in animal products antibiotic residues were found, therefore research was needed. The purpose of this observation is to find out antibiotic residues on beef marketed in Bali.

\section{II.MATERIALS AND METHODS}

This study used 60 beef samples from 5 markets: Negara, Tabanan, Denpasar, Singaraja, and Klungkung, each market with 12 samples. Sreening test used to determine aminoglycoside dan macrolide. Materials and tools used include: $8 \mathrm{~mm}$ diameter disc paper, $100 \times 12 \mathrm{~mm}$, petri dish, test tube, measuring flask, centrifuge tube, erlenmeyer, volumetric pipette, graduation pipette, and a media bottle (roux's bottle). Other tools are centrifuges, water baths, sterile cabinets, homogenizers, autoclaves, refrigerators, freezers, analytic scales, incubators, stirring magnets and $\mathrm{pH}$ meters. The supporting tools include micro pipette 50-300 $\mu \mathrm{l}$, calipers runner, burner, ose, tweezers, and scissors.

The procedures are as follows:

- Making comparable standard aminoglycoside solutions (as stock), ie. dissolving aminoglycoside hydrochloride into distilled water to a concentration of $1000 \mu \mathrm{g} / \mathrm{ml}$. Then make a standard macrolide comparison solution by dissolving sodium macrolide in buffer solution to obtain $1000 \mu \mathrm{g} / \mathrm{ml}$. Then stored in the refrigenerator.
- Make serial aminoglycoside and macrolide concentrations. Make aminoglycoside concentrations from a concentration of $0.25 ; 0.50$; $1.0 ; 2.0$ and $4.0 \mu \mathrm{g} / \mathrm{ml}$ while the macrolides of the concentration were $0.0025 ; 0.005 ; 0.01 ; 0.02$; and $0.04 \mathrm{IU} / \mathrm{ml}$. Putting the standard solution into disc paper as much as $75 \mu 1$ and phosphate buffer solution as negative control, are waited until all of them are absorbed. Put in petri and put it at room temperature for 1 to 2 hours. The aminoglycosides were then added to the incubator at a temperature of $550 \mathrm{C}$ while the macrolide was at 300 C. For 16 hours, respectively. Measuring the diameter of the barrier formed. Make a linear curve that describes the relationship between antibiotic concentration and the diameter of the obstacle area manually.

- Sample preparation (sample). Ten grams of meat cut into small pieces placed in erlenmeyer added $20 \mathrm{ml}$ of buffer solution, then homogenized using a homogenizer. At $3000 \mathrm{rpm}$ centrifuge for 10 minutes and take the supernatant. This supernatant is ready to be used as a test sample solution.

- Test implementation. Mix $1 \mathrm{ml}$ of bacteria with agar medium, then pipette the mixture of agar media and the bacteria as much as $8 \mathrm{ml}$. into petridis, where each type of antibiotic uses three petri dishes. Let it freeze. Next drip the standard solution and buffer solution into each of the $75 \mu$ disc paper until evenly distributed. Next put the paper disc into a petri dish and incubated at $36^{\circ} \mathrm{C}$ for aminoglycosides and $55^{\circ} \mathrm{C}$ for macrolides for 16 hours. The reading of the results by measuring the diameter of the obstacle area formed around the disc paper. Also 
done on positive control and negative control. Positive control must form an area of resistance while negative control is the opposite. The appearance of a transparent area around the disc paper shows positive meat for antibiotic residues.

\section{RESULT AND ANALYSIS}

The results showed that $3.33 \%$ were positive for antibiotics, including aminoglycosides and $1.67 \%$ positive for macrolides. The full results are presented in Table 1. below.

\section{TABLE 1. TEST RESULTS OF ANTIBIOTIC RESIDUES IN BALI BEEF}

\begin{tabular}{lllll}
\hline \multirow{2}{*}{$\begin{array}{l}\text { Origin } \\
\text { meat }\end{array}$} & of $\begin{array}{l}\text { Number } \\
\text { samples } \\
\text { (peach) }\end{array}$ & Aminoglycoside & Macrolide & \\
\cline { 4 - 5 } \cline { 5 - 5 } Denpasar & 12 & 0 & 0 & \\
Tabanan & 12 & 0 & 0 & A positive \\
Negara & 12 & 2 & 1 & total of 5\% \\
Singaraja & 12 & 0 & 0 & \\
Klungkung & 12 & 0 & 0 & \\
Total & 60 & 2 & 1 & $1,67 \%$ \\
\hline Percentage & & $3,33 \%$ & & \\
\hline
\end{tabular}

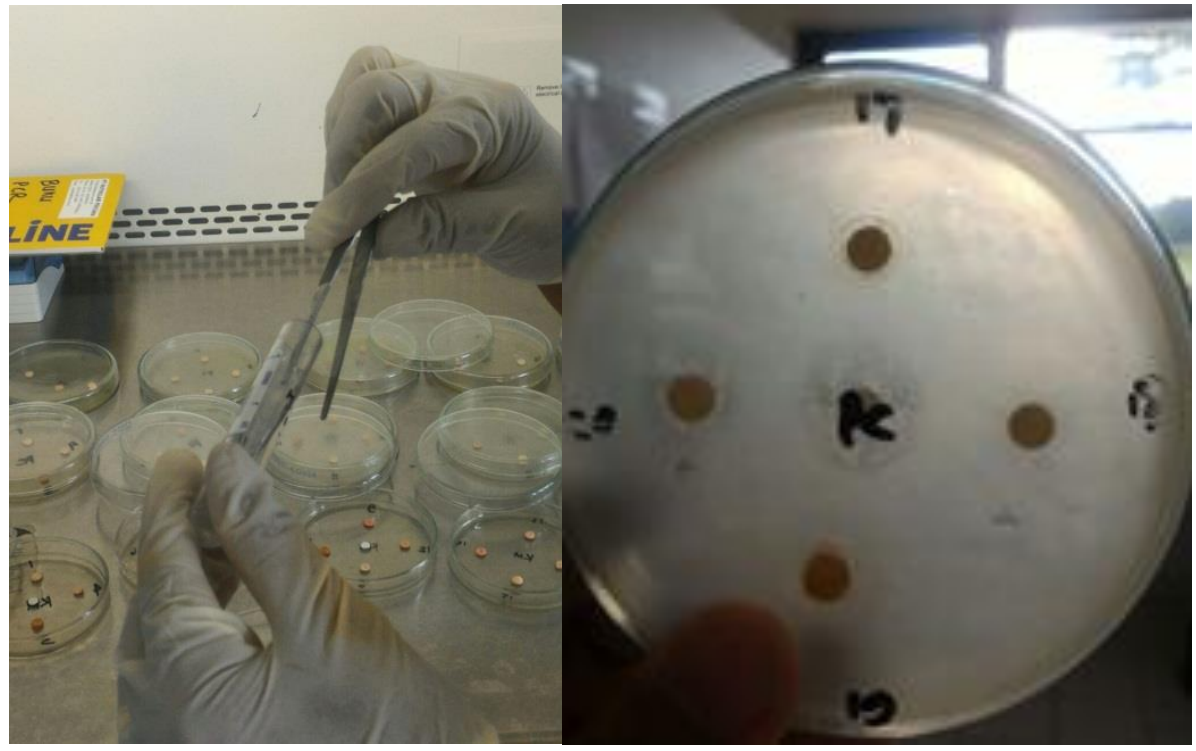

Figure 1. Screening test indicate negative

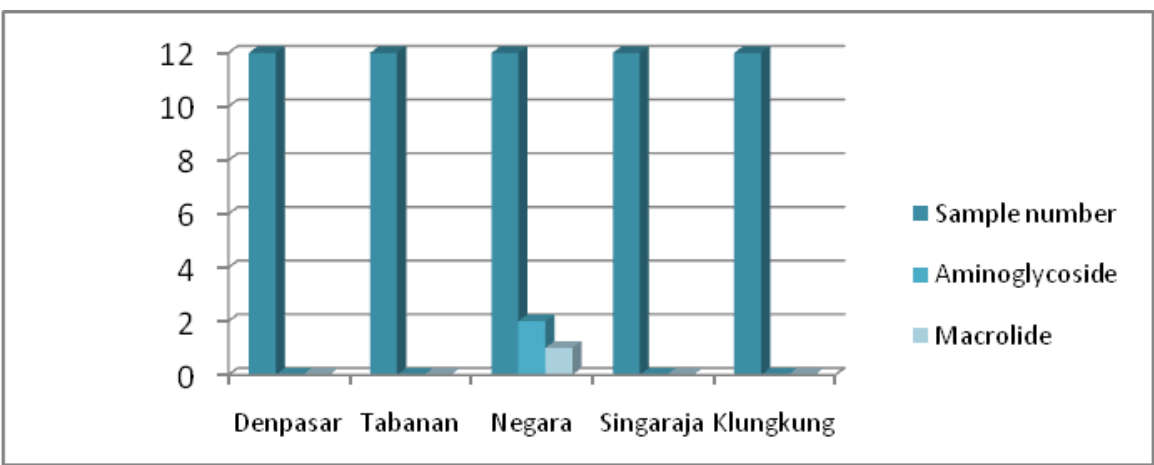

Figure 2. Comparison of the number of samples with positive antibiotics 
The results show that the city of the Negara has the opportunity for meat products that still contain antibiotic residues. However, the low percentage of beef containing antibiotic residues in some markets in Bali is relatively safe for consumption by the consumer. This low of beef positive on antibiotic residues can be caused by unused cattle using antibiotics as growth stimulants or weight enhancers. Observations in the field, that cattle come from traditional farms but known do not use antibiotics as growth boosters).

The low percentage of antibiotic residues in meat can be caused by the slaughter of cattle is being treated with antibiotics. Not yet withdrawal time, the animal is slaughtered. So, it's not caused the use of antibiotics as growth boosters. However, the animal that should be slaughter must be free from antibiotics, so that the animal product free from antibiotic residues. If an animal is to be sold and will be slaughter for consumption, it's must wait until withdrawal time. In poultry and dairy farms, the use of antibiotics is often done, to prevent bacterial infections and enhanced body weight, but in dairy farms antibiotic are used for the prevention and treatment in mastitis.

The finding antibiotic residues in beef marketed in several markets in Bali, can be caused by the use of antibiotics as a treatment for sick cows. The low percentage of antibiotic residues in beef in Bali can be cause by the treatment / injection of animals sick and not yet withdrawal time, the animals are sold and slaughter for consumption. So, it is not caused by the use of antibiotics as growth boosters. To compared with residues in chicken and cow's milk, the residue in beef is relatively smaller. Chicken and cow's milk are animal products that most often contain antibiotic residues. Wijaya, M.R. (2011) and Yuningsih, (2009), say high antibiotic residues in chickens and milk. Sattar et al., (2015) reported that there were $48 \%$ of residue antibiotics in the liver, $24 \%$ in the kidneys, $20 \%$ in the thigh muscles, and $24 \%$ in the chicken breast muscles.

\section{V.CONCLUSION}

According to these results, that beef marketed in several markets in Denpasar, Tabanan, Negara, Singaraja, and Klungkung arepositive aminoglycosides $3.33 \%$ and $1.66 \%$ macrolides.

\section{SUGGESTION}

It is recommended to keep monitoring regularly on meat products marketed in traditional and modern markets in Bali.

\section{REFERENCES}

[1] Ashton, A.Q. (2012). Macrolide Antibiotics-Advances in Research and Application. Scolarly Editions. Atlanta, Gergia, USA.

[2] Bayou, K., and Haile, N. (2017). Review on Antibiotic Residues in Food of Animal Origin: Economic and Public Health Impacts. Applied Journal of Hygiene 6 (1): 01-08, 2017. DOI:

10.5829/idosi.ajh.2017.01.08.

[3] Beyene, T. (2016) Veterinary Drug Residues in Food-animal Products: Its Risk Factors and Potential Effects on Public Health. J Veterinar Sci Technol 7:285. doi:10.4172/21577579.1000285

[4] Gottlieb, D., Shaw, P.D. (2013). Antibiotics I: Mechanism of Action. Springr-Verlag. Berlin Heidelberg GmbH.

[5] Gualerzi, C.O, Brandi, L, Fabbretti, A., Pon, C.L. (2013). Antibiotics: Targets, Mechanisms and Resistance. ${ }^{1 \text { st }}$ ed. John Wiley \& Sons, Incorporated. 
[6] Katz, E.S., and Brady, M.S. (2009). Antibiotic residues in food and their significance. Food Biotechnology. Volume 14, 2000 - Issue 3. Pages 147-171.

[7] Masrianto, and Azhari, F. (2013). Uji Residu Antibiotika Pada Daging Sapi Yang Dipasarkan Di Pasar Tradisional Kota Banda Aceh. Jurnal Medikal Veterinaria Vol. 7, No. 1, Februari 2013. ISSN: 0853-1943 13.

[8] Murdiati, T.B. (1997). Pemakaian Antibiotika Dalam Usaha Peternakan. Wartazoa Vol. 6 No. 1 Th 1997. Balai Penelitian Veteriner. Bogor 16114.

[9] Patricia, L., Keen, P.L., Montforts, M.H. (2012). Antimicrobial Resistance in the Environment. Published by John Wiley \& Sons, Inc., Hoboken, New Jersey.Canada.

[10] Pavlov, L., Lashev, I., Vachin, V.R. (2008). Residues of Antimicrobial Drugs in Chicken Meat and Offals. Trakia Journal of Sciences, Vol. 6, Suppl. 1, pp 23-25, 2008. Faculty of Veterinary Medicine, Trakia University, Stara Zagora.

[11] Satta, S., Hassan, M.M., Islam, A., Alam, M.M., Al-Faruk, S., Chowdhury, S., and Saifuddin. (2014). Antibiotic residues in broiler and layer meat in Chittagongdistrict of Bangladesh. Veterinary World, EISSN: 2231-0916, Vol.7/September-2014.

[12] Shareef, A.M., Jamel, Z.T., Yonis, K.M. (2009). Detection of antibiotic residues in stored poultry products. Iraqi Journal of Veterinary Sciences, Vol. 23, Supplement I, 2009 (45-48.
[13] Singh, O.V. (2017). Foodborne Pathogens and Antibiotic Resistance Edited by John Wiley \& Sons. Published by John Wiley \& Sons, Inc., Hoboken, New Jersey. Canada.

[14] Wang, J., MacNeil, J.D., Kay, J.F. (2011). Chemical Analysis of Antibiotic Residues in Food. Vol.: 38. $1^{\text {st }}$ ed. Publisher John Wiley \& Sons, Incorporated. p. 377.

[15] Wijaya, M.R. (2011). Residu Antibiotika pada Daging Ayam dan Sapi dari Pasar Tradisional di Provinsi Jawa Barat. Repository. Institut Pertanian Bogor. Bogor.

[16] Williams, J.D., Geddes, A.M. (2012). Pharmacology of Antibiotics. Springer Science and Business Media. New York, USA.

[17] Yamaguchi, T., Okihashi, M., Harada, K., Konishi, Y., Uchida, K., Do, M.H.N., Bui, H.D.T., Nguyen, T.D., Chau, V.V., Dao, K.T., Nguyen, H.T.N., Kajimura, K., Kumeda, Y., Trong Bui, C.T., Vien, M.Q., Le, N.H., Hirata, K., and Yamamoto, Y. (2015). Antibiotic Residue Monitoring Results for Pork, Chicken, and Beef Samples in Vietnam in 2012-2013. J Agric. Food Chem., 2015, 63 (21), pp 51415145.

[18] Yuningsih. (2009). Keberadaan Residu Antibiotika Dalam ProdukPeternakan(Susu Dan Daging). Lokakarya Nasional Keamanan Pangan Produk Peternakan48. Balai Penelitian Veteriner. Bogor. 